Article

\title{
Don't Good Democracies Need “Good” Citizens? Citizen Dispositions and the Study of Democratic Quality
}

\author{
Quinton Mayne ${ }^{1, *}$ and Brigitte Geißel ${ }^{2}$ \\ ${ }^{1}$ Kennedy School of Government, Harvard University, Cambridge, MA 02138, USA; E-Mail: quinton_mayne@harvard.edu \\ ${ }^{2}$ Institute of Political Science, Goethe University, 60629 Frankfurt am Main, Germany; E-Mail: geissel@soz.uni-frankfurt.de \\ * Corresponding author
}

Submitted: 5 October 2017 | Accepted: 29 January 2018 | Published: 19 March 2018

\begin{abstract}
This article advances the argument that quality of democracy depends not only on the performance of democratic institutions but also on the dispositions of citizens. We make three contributions to the study of democratic quality. First, we develop a fine-grained, structured conceptualization of the three core dispositions (democratic commitments, political capacities, and political participation) that make up the citizen component of democratic quality. Second, we provide a more precise account of the notion of inter-component congruence or "fit" between the institutional and citizen components of democratic quality, distinguishing between static and dynamic forms of congruence. Third, drawing on crossnational data, we show the importance of taking levels of inter-dispositional consistency into account when measuring democratic quality.
\end{abstract}

\section{Keywords}

citizens; democracy; democratic commitments; political capacity; political participation; quality of democracy

Issue

This article is part of the issue "Why Choice Matters: Revisiting and Comparing Measures of Democracy", edited by Heiko Giebler (WZB Berlin Social Science Center, Germany), Saskia P. Ruth (German Institute of Global and Area Studies, Germany), and Dag Tanneberg (University of Potsdam, Germany).

(C) 2018 by the authors; licensee Cogitatio (Lisbon, Portugal). This article is licensed under a Creative Commons Attribution 4.0 International License (CC BY).

The health and stability of a modern democracy depends, not only on the justice of its "basic structure" but also on the qualities and attitudes of its citizens. (Kymlicka \& Norman, 1994, p. 352)

\section{Introduction}

Large-scale, cross-national indices of democratic quality have traditionally paid little systematic attention to citizens as a constitutive component of democratic quality. In earlier work (Mayne \& Geissel, 2016), we challenged this orthodoxy by highlighting the importance of citizens as central to the conceptualization of democratic quality. Specifically, we argued that democratic quality con- sists of two necessary, but independently insufficient, components. First, an "institutional component", which dominates research on democratic quality, refers to the institutional and structural opportunities that allow for democratic rule. Second, a "citizen component" relates to the ways in which citizens can and do breathe life into existing institutional opportunities for democratic rule. ${ }^{1}$ We identified three broad categories of citizen dispositions as constitutive of the citizen component: namely, democratic commitments, political capacity, and political participation.

Providing a structured account of how citizens lie at the core of the concept of democratic quality is important for both scholarly and practical reasons. By includ-

\footnotetext{
${ }^{1}$ This should not be confused with quality-of-democracy research that takes citizens into account using data on mass public assessments of political actors and institutions (see, e.g., Logan \& Mattes, 2012; Pickel, Breustedt, \& Smolka, 2016). These kinds of public opinion data are unrelated to what we refer to here as the citizen component of democratic quality; instead, they provide (non-expert evaluative) information on the institutional component of democratic quality.
} 
ing measures of electoral turnout, many existing studies in this area partially or implicitly acknowledge that highquality institutions are not enough; a high-quality democracy also requires citizens to use these institutions. Participation in elections is, however, only one part of the citizen component of democratic quality. To advance theoretical and empirical research in this area, it is necessary to develop a systematic understanding of the place of citizens within the concept of democratic quality. That is the goal of this article. To this end, we expand the empirical underpinnings of the study of democratic quality by bringing it into conversation with research from political behavior and political psychology. We also deepen the engagement of quality-of-democracy research with political theory and political philosophy. Existing work on democratic quality is often anchored in partial readings of normative accounts of democracy, focused on extracting what these accounts have to say about institutions. As we show here, these same accounts have a great deal to say about the kinds of citizen dispositions that are constitutive of a high-quality democracy.

Taking citizens more seriously in how we understand democratic quality also brings research in line with the realities of national and international programs aimed at supporting and deepening democracy. Publicly-funded and philanthropic work has long had both an institutional and a citizen component, seeking to improve the quality of institutions as well as impact the values, competences, and participatory proclivities of citizens. Traditionally this work has been targeted at new, low- and middle-income democracies, but-amidst growing fears of democratic deconsolidation (Foa \& Mounk, 2017; Levitsky \& Ziblatt, 2018)-there has been an upsurge in interest in democratic programming in advanced industrial societies. By fully incorporating citizens into the conceptualization of democratic quality, we hope to bridge the existing gap between practice and research, enabling work on quality of democracy to speak to efforts of leaders and organizations working in the space of democracy promotion.

In the pages that follow, we aim to provide a solid analytic foundation and conceptual framework to incorporate data on the citizen component of democratic quality in future empirical research. We do this by building on our earlier work in three ways. In the next section, we provide a more fine-grained and structured conceptualization of democratic commitments, political capacities, and political participation. In the second section of the article, we address the question of congruence or "fit" between the institutional and citizen components of democratic quality. Third, we develop the idea that the degree of consistency of democratic commitments, political capacities, and political participation with the same model of democracy is an important aspect of democratic quality. We illustrate the issues of inter-component congruence and inter-dispositional consistency using available cross-national empirical data. The article ends with a discussion of the significant limitations of existing international survey programs as sources of data for measuring the citizen component of democratic quality.

\section{Citizen Dispositions}

Just as the Varieties of Democracy project (Coppedge et al., 2011) has shown that different models of democracy value different kinds of institutional arrangements, it is important to recognize that there is no one-size-fits-all understanding of the core dispositions that comprise the citizen component of democratic quality. We therefore focus our attention on how three models of democracy, which have long dominated academic and policy debates, understand each disposition. This includes: minimalelitism-epitomized by the work of Joseph Schumpeter (1950) and E. E. Schattschneider (1975); liberal-pluralism, defined and developed perhaps most famously in the work of Robert Dahl (1971, 1989); and participatory democracy, championed by scholars such as Carole Pateman (1970) and Benjamin Barber (1984). ${ }^{2}$

\subsection{Democratic Commitments}

That democratic commitments are a necessary component of democratic quality finds support in a long line of writing. As John Stuart Mill (1861/2009, p. 7) noted, "the people for whom the [democratic] form of government is intended must be willing to accept it". Democratic commitments refer to the political beliefs, values, principles, and norms that citizens hold dear. They combine both cognitive and affective orientations, which citizens use to understand and judge the political world. A sizeable body of empirical research has emerged in recent years on how citizens understand democracy (Bratton, Mattes, \& Gyimah-Boadi, 2005, Chapter 3; Canache, 2012; Carrión, 2008; Dalton, Sin, \& Jou, 2007; Fuchs \& Roller, 2006; Kornberg \& Clarke, 1994; Miller, Hesli, \& Reisinger, 1997; Silveira \& Heinrich, 2017; Thomassen, 1995), but the literature on the more specific question of which democratic values and principles citizens actually endorse is still fairly limited (Carlin, 2017; Carlin \& Singer, 2011; Hibbing \& Theiss-Morse, 2002; Kriesi, Saris, \& Moncagatta, 2016; Lalljee, Evans, Sarawgi, \& Voltmer, 2013; McClosky, 1964; Schedler \& Sarsfield, 2007).

The concept of democratic commitment operates at two levels: at a general level in the form of citizens' broad preference for democracy over non-democratic forms

\footnotetext{
2 In this article we are argue that citizens are constitutive of the concept of democratic quality; we are silent on the question of whether the concept of democracy itself includes a citizen component. We note, however, that the answer to this question has been a resounding no. Scholarship has predominantly distinguished democracies from non-democracies (or hybrid regimes) in one of two ways: based exclusively on electoral procedures (e.g., Przeworksi, Alvarez, Cheibub, \& Limongi, 2000); or using a more expansive set of procedural criteria, that take account of not just the quality of electoral processes but also the protection of civil liberties and civilian control of the military, among other things (e.g., Mainwaring, Brinks, \& PérezLiñán, 2007). The first approach distinguishes democracies based on institutions that lie at the heart of the minimal-elitist conception of democracy; the second approach is anchored more in the liberal-pluralist account of democracy. In both cases, selection criteria are essentially institutional.
} 
of political organization; and at a more specific level in terms of citizens' support for particular principles and values. The idea that democracies require citizens' general democratic commitment finds clear support in work on democratic consolidation as well as democratic deconsolidation. ${ }^{3}$ Building on this research, we understand democratic quality as being in part a function of how committed citizens are to democracy, even in the face of mobilization by anti-democratic forces, economic misfortune, and electoral losses.

The study of democratic quality requires going beyond this general commitment to democracy and taking into account citizens' commitments to more specific democratic values. Pragmatically, this makes it easier to identify whether citizens' general democratic commitment is in fact nominal and without meaningful content; it is also necessary because different models of democracy set store by different types of political values. A theory-driven approach requires being clear on how the model(s) of democracy underpinning one's assessment interpret core democratic principles in different ways, or even accommodate different democratic principles. To gain analytic purchase on the issue of democratic commitments, we propose that scholars focus on the principled responses that different models of democracy provide to the following two questions. First, who gets to decide? Second, how are decisions to be made? ${ }^{4}$

The question of who gets to decide is first and foremost about what citizens consider to be the proper role of elected politicians in democratic decision making. A helpful way of thinking about this issue is in terms of the checks and balances that different models of democracy expect citizens to support, which concerns the power of elected politicians relative to other "political" actors, e.g., the judiciary or subnational authorities. It also concerns checking and balancing among different classes of politician, most notably between the executive and legislature. Finally, the question of who gets to decide is crucially linked to what citizens see as their own role, acting individually or collectively, in democratic decision making.

The second question of how decisions are to be made relates to citizens' settled opinions on how core democratic principles should be instantiated in democratic processes and structures. This fundamentally concerns not just the formal rules but also the institutionalized norms of encounter and exchange between elected politicians and other political actors. Different models of democracy demand, explicitly and implicitly, different commitments from citizens when it comes to how democratic decisionmaking processes should take place. As a result, judgements of any one country's democratic quality will vary greatly depending on the model used to carry out the assessment. This becomes clear by looking at the democratic commitments expected of citizens by the three key models of democracy (a summary of which is available in Table 1).

The minimal-elitist account of democracy envisages citizens to be committed to forms of decision making dominated by parties, elected politicians, and the government of the day, with few checks and balances. Citizens are expected to willingly accept their own voluntary "retirement" (to borrow the words of Schumpeter, 1950, p. 295) from political life between elections. As to the question of how decisions are to be made, high-quality minimal-elitist democracy is predicated on the expectation that citizens will be tolerant of political differences and supportive of robust competition between those differences at the ballot box. However, once votes are cast, minimal-elitism expects citizens to support winner-takeall majoritarianism, which necessarily implies electoral losers (even perennial electoral losers) accepting their political marginality.

High-quality liberal-pluralist democracies are also home to citizenries that support elected politicians as the primary decision-makers. However, "good" liberalpluralist citizens are additionally expected to be committed to the idea that politicians are checked and balanced in important ways, for example by constitutional protections and judicial oversight, or by divisions of power between the executive and legislature, i.e., decision making that involves elected and unelected elites. Citizens are expected to embrace their own role in democratic decision making as largely mediated: by the parties/politicians they elect, and by the interest organizations who speak on their behalf. Liberal-pluralists expect citizens to accept or even welcome that public policy will be influenced by processes of consultation and lobbying, involving politically independent intermediary organizations and associations. By extension, the "good" liberalpluralist citizen is expected to see negotiation and compromise among elites of different political persuasions as a natural and proper part of the democratic process. $^{5}$

The participatory model of democracy is distinct from minimal-elitism and liberal-pluralism in that it expects citizens to support unmediated forms of mass popular involvement in democratic decision making. This might include support for direct democratic mechanisms that allow citizens to vote on specific issues as well as participatory innovations (such as participatory budgeting and citizen juries) that give citizens decision-making powers. While the participatory model of democracy clearly sets great store by the idea that final decisionmaking powers should lie with citizens themselves in at

\footnotetext{
${ }^{3}$ As Juan Linz and Alfred Stepan note, "a democratic regime is consolidated when a strong majority of public opinion, even in the midst of major economic problems and deep dissatisfaction with incumbents, holds the belief that democratic procedures and institutions are the most appropriate way to govern collective life" (Linz \& Stepan, 1996, p. 16; see also Diamond, 1999, p. 69; Foa \& Mounk, 2017).

${ }^{4}$ These two questions effectively amount to two sides of the same coin of democratic decision making, and as such are likely difficult to separate empirically.

${ }^{5}$ Significant variations exist within the liberal-pluralist understanding of democracy, which encompasses classic forms of pluralistic decision making as well as consensus or negotiation democracy (Lijphart, 1999).
} 
Table 1. The citizen component.

\begin{tabular}{|c|c|c|c|c|}
\hline \multirow[t]{2}{*}{ Core Dispositions } & \multirow[t]{2}{*}{ Key Elements } & \multicolumn{3}{|c|}{ The "good" citizen according to: } \\
\hline & & $\begin{array}{l}\text { Minimal-elitist } \\
\text { model }\end{array}$ & $\begin{array}{l}\text { Liberal-pluralist } \\
\text { model }\end{array}$ & $\begin{array}{l}\text { Participatory } \\
\text { model }\end{array}$ \\
\hline $\begin{array}{l}\text { 1. Democratic } \\
\text { commitments }\end{array}$ & $\begin{array}{l}\text { Commitment regarding: } \\
\text { - Who gets to decide? } \\
\text { - How decisions should } \\
\text { be made? }\end{array}$ & $\begin{array}{l}\text { Committed to } \\
\text { decision making } \\
\text { dominated by } \\
\text { parties and } \\
\text { elected } \\
\text { politicians, with } \\
\text { few checks and } \\
\text { balances. }\end{array}$ & $\begin{array}{l}\text { Committed to } \\
\text { electoral } \\
\text { democracy where } \\
\text { politicians are } \\
\text { checked and } \\
\text { balanced and } \\
\text { intermediary } \\
\text { organizations play } \\
\text { important role. }\end{array}$ & $\begin{array}{l}\text { Committed to } \\
\text { unmediated forms of } \\
\text { mass popular } \\
\text { involvement in } \\
\text { democratic decision } \\
\text { making and idea that } \\
\text { politicians should } \\
\text { actively consult } \\
\text { citizens between } \\
\text { elections. }\end{array}$ \\
\hline $\begin{array}{l}\text { 2. Political } \\
\text { capacities }\end{array}$ & $\begin{array}{l}\text { Capacity to: } \\
\text { - know } \\
\text { - choose } \\
\text { - influence }\end{array}$ & $\begin{array}{l}\text { Capable of } \\
\text { selecting into } \\
\text { their values, } \\
\text { preferences, and } \\
\text { interests based on } \\
\text { menu of options } \\
\text { provided to them } \\
\text { by political elites } \\
\text { in lead up to } \\
\text { elections. }\end{array}$ & $\begin{array}{l}\text { Capable of } \\
\text { enlightened } \\
\text { understanding of } \\
\text { their own interests } \\
\text { and sufficiently } \\
\text { tuned into politics to } \\
\text { be able to identify and } \\
\text { support, if need be, } \\
\text { organizations that } \\
\text { can defend their } \\
\text { values and interests. }\end{array}$ & $\begin{array}{l}\text { Possessing skills and } \\
\text { knowledge that } \\
\text { enable them to } \\
\text { cooperate, } \\
\text { communicate, and } \\
\text { deliberate with } \\
\text { fellow citizens and } \\
\text { political elites. }\end{array}$ \\
\hline $\begin{array}{l}\text { 3. Political } \\
\text { participation }\end{array}$ & $\begin{array}{l}\text { Participation that is: } \\
\text { - Electoral vs. non-electoral } \\
\text { - Mediated vs. direct } \\
\text { - Other-regarding }\end{array}$ & $\begin{array}{l}\text { Pay sufficient } \\
\text { attention to } \\
\text { politics during } \\
\text { election campaign } \\
\text { to avoid being } \\
\text { duped and turn } \\
\text { out to vote, if } \\
\text { interests at stake. }\end{array}$ & $\begin{array}{l}\text { No duty to } \\
\text { participate actively } \\
\text { in politics, but } \\
\text { ideally occasionally } \\
\text { undertakes mainly } \\
\text { mediated forms of } \\
\text { participation. }\end{array}$ & $\begin{array}{l}\text { Directly and actively } \\
\text { involved in politics } \\
\text { on an ongoing basis, } \\
\text { with emphasis on } \\
\text { other-regarding and } \\
\text { public-oriented } \\
\text { political activities. }\end{array}$ \\
\hline
\end{tabular}

least certain issue or policy areas, it also demands that where elected politicians retain decision-making powers they should undertake continuous processes of consultation with citizens between elections. This is one of the chief differences between participatory democracy and minimal-elitism and liberal-pluralism when it comes to the question of "how" decisions should be made.

\subsection{Political Capacity}

Existing cross-national indices of democratic quality rarely include indicators capturing levels of political capacity among citizenries. ${ }^{6}$ This contrasts with statements on the importance of political capacity made by democratic theorists of various stripes as well as the growing fears expressed by political commentators of citizens' incapacity to resist misinformation. The absence of direct measures of political capacity from existing quality-ofdemocracy indices also runs counter to the large body of empirical research on political capacity within the field of political behavior. Key questions that have animated this research include: are citizens able to maintain internallyconsistent and ideologically-structured beliefs? How politically knowledgeable and civically literate are citizens? Do citizens interrogate their own beliefs by finding and accurately processing new or unbiased sources of political information? How capable are citizens of voting for politicians and parties that will best represent their values and interests? ${ }^{7}$ Debates among empirical political scientists regarding how much and what kinds of political

\footnotetext{
${ }^{6}$ An exception is the Democracy Ranking (Campbell, 2008), which includes measures of secondary-school and university enrolment aimed at capturing the availability of "knowledge" in a society. The Economist Intelligence Unit's (EIU) Democracy Index includes data on levels of adult literacy and the share of the population that follows politics in the news.

7 See, for example, Achen \& Bartels, 2016; Alvarez \& Nagler, 2000; Andersen, Tilley, \& Heath, 2005; Arnold, 2012; Barabas \& Jerit, 2009; Bartels, 1996; Campbell, Converse, Miller, \& Stokes, 1960; Converse, 1964; Delli Carpini \& Keeter, 1996; Lau, Patel, Fahmy, \& Kaufman, 2014; Lavine, Johnston, \& Steenbergen, 2012; Lodge \& Taber, 2013; Lupia, 2016; Milner, 2002; Mutz, 2006; Nie, Junn, \& Stehlik-Barry, 1996; Page \& Shapiro, 1992; Rapeli, 2014; Rosema \& de Vries, 2011; Zaller, 1992.
} 
capacity are required of citizens for democracy to flourish is reflective of important conceptual disagreements about what makes a democracy high quality. All major models of democracy clearly identify political capacity as important for democracy; they differ significantly however in their understanding of what types and levels of political capacity matter for high-quality democracy.

How exactly then do different models of democracy understand the concept of political capacity? To answer this question, we propose focusing on three types of political capacity. The first is the capacity of citizens to understand or know their own values, preferences, and interests that they wish to see realized through the democratic process. The second is the capacity of citizens to identify and select elites who will defend and advance those values, preferences, and interests in the political arena. The third and final capacity is the capacity to influence political elites and the agendas they pursue. For the sake of simplicity, we refer to these three core democratic capacities as the capacity to know, the capacity to choose, and capacity to influence. For a summary of how these three capacities are understood by three key models of democracy, see Table 1.

Let us first turn to the capacity to know. For advocates of minimal-elitist democracy, little is expected of citizens. Schumpeter famously argued that citizens are "incapable of action other than a stampede" (1950, p. 283); such low levels of political capacity associated with stampede-like cognition and affect are seen as in no way undermining a country's quality of democracy. For minimal-elitists, citizens need only be capable of selecting into their values, preferences, and interests based on the menu of options provided to them by political elites during the short window of public debate that periodically occurs prior to elections. That said, as Schumpeter points out, for minimalelitist democracy to work well, citizens must be on "an intellectual and moral level high enough to be proof against the offerings of the crook and the crank" (1950, p. 294, emphasis added). This suggests that the "good" citizen for minimal-elitists is able to process the content of preelection public debate in ways that allow her to identify and resist the siren call of false information.

Liberal-pluralist and participatory models of democracy are more demanding of citizens in terms of their "capacity to know" their own values and interests. Both models share an expectation that citizens should have the capacity to arrive at what Tocqueville described as "self-interest rightly understood" or what Dahl refers to as "enlightened understanding". In Democracy and Its Critics (1989, pp. 111-112), Dahl writes that "to know what it wants, and what is best, the people must be enlightened". To achieve such enlightenment, Dahl argues that citizens must acquire "an understanding of means and ends, of one's interests and the expected consequences of policies for interests, not only for oneself but for all other relevant persons as well". 8 The implication of this is that citizens are expected to be capable of finding and processing information and weighing the consequences of their values and interests on those of fellow citizens.

When it comes to citizens' capacity to choose political elites who will defend and pursue their interests, minimal-elitist, liberal-pluralist, and participatory models of democracy have much in common. None of them requires citizens to be extraordinary information sleuths or indeed policy wonks; rather, they expect citizens to be capable of taking full advantage of elite-provided sources of structured information in order to choose leaders without, as Schattschneider $(1975$, p. 134) puts it, being duped by demagogues. The models diverge, however, along two dimensions: first, in terms of the range of elite actors that citizens are expected to select; and second, in terms of the period of time over which citizens are expected to select elites.

For minimal-elitists, the "good" citizen need only be able to tune into politics in short bursts at election time. Using information shortcuts generated by the process of political competition during the campaign period, citizens are expected to have the political wherewithal to select candidates and parties who will best serve their values and interests. For liberal-pluralists (see Galston, 1988, p. 1283) and participatory democrats, citizens are also expected to be able to make sense of available information to select the right candidates and parties at election time. In addition, they must be sufficiently tuned into politics on an ongoing basis to be able to identify and support organizations and associations that will defend their values and interests, as and when the need arises, by applying pressure on elected politicians between elections.

Finally, what do the three models have to say about citizens' capacity to influence? Minimal-elitists expect citizens to influence politics and policy making indirectly through their vote choices and certainly not between elections. Liberal-pluralist and participatory democrats expect citizens to influence elites through forms of Hirschmanian exit and voice. To influence elites via voice requires citizens to possess cognitive, expressive, and organizational capacities. This includes the ability to identify whom to target and the capacity to work with others to influence them. For participatory democrats, who argue that high-quality democracies provide wide-ranging opportunities for citizens to get involved in shaping public policy, it is particularly important that citizens possess skills and knowledge that enable them to cooperate, communicate, and deliberate with fellow citizens and political elites alike (see Barber, 1984, p. 154).

\subsection{Political Participation}

One of the few citizen-related indicators that routinely appears in existing cross-national quality-of-democracy

\footnotetext{
${ }^{8}$ For in-depth discussions of the capacities expected of the "good" liberal citizen, see Galston (1988, especially pp. 1283-1285) and Macedo (1990, especially pp. 265-273). For the capacities required of the "good" participatory citizen, see the discussion of "strong democratic talk" in Barber (1984, pp. 178-198).
} 
indices is turnout in national elections (see Altman \& Pérez-Liñán, 2002; Bühlmann et al., 2013; EIU, 2012; Levine \& Molina, 2011). ${ }^{9}$ This clearly points to a scholarly consensus that political participation is a core conceptual component of democratic quality. High-quality democracy cannot simply be understood in terms of the existence of particular kinds of democratic institutions, the most incontrovertible of which are free and fair elections; it is also defined by whether citizens actually turn out to vote in those elections. All major models of democracy set great store by electoral participation. They do differ significantly though in the importance they attach to other forms of political participation.

Over the years normative disagreements among political theorists and political philosophers have inspired and echo similar debates among scholars of political behavior. In fact, the question of what types of political participation are found in high-quality democracies goes back to one of the founding studies in the field of political behavior, The Civic Culture by Gabriel Almond and Sidney Verba (1963), who argued that democracies are best served by citizens who "balance" political activity and passivity. In the half-century since the publication of The Civic Culture, patterns of popular political participation have changed greatly. However, the question of how active citizens should be, and what forms political activity should take remains central to the study of political behavior. ${ }^{10}$

To capture how different models of democracy conceive of political participation, we propose that scholars of democratic quality pay particular attention to how much weight is attached to: (1) participation focused on elections versus acts of political participation that occur between elections; (2) mediated forms of political participation where citizens seek to influence politics through organized civil society versus direct forms of political action and participation; and (3) the extent to which political participation is "other-regarding" and public-oriented. See Table 1 for a summary of the discussion below.

For minimal-elitists, elections are the singular focus of citizen participation. The primary political act of the "good" citizen is therefore to turn out in periodic elections. To avoid political demagoguery, it can be assumed that minimal-elitists expect citizens to pay attention to politics during election campaign periods, consume political news, and engage in political discussions. ${ }^{11}$ Between elections, however, citizens are expected to engage in few, if any, political acts, leaving politics to politicians and parties.
For liberal-pluralists, citizens are under no duty to participate actively in politics (Galston, 1988, p. 1284). That said, there is an expectation that they will turn out to vote, in line with their self-interest rightly understood. This implies that the "good" liberal-pluralist citizen will engage in forms of other-regarding political activities that allow her to achieve an "enlightened" understanding of her values and interests. The emphasis is placed on forms of mediated political participation, most notably engagement with organizations and associations, and by extension social movements. There is also an expectation that in a high-quality liberal-pluralist democracy, citizens will-to quote Stephen Macedo (1990, p. 274)"take initiatives on their own [and] be prepared to combine in voluntary associations for common ends both altruistic and otherwise".

For participatory democrats, citizens are expected to be engaged in the electoral process in similar ways to the "good" liberal-pluralist citizen. However, the participatory model of democracy places a duty on citizens to be directly and actively involved in politics on an ongoing politics. As Barber (1984, p. 152) writes, "[participatory] democracy is the politics of amateurs, where every man is compelled to encounter every other man without the intermediary of expertise". Finally, as these words suggest, participatory democrats also expect citizens to undertake political activities that are expressly other-regarding and public-oriented, aimed at moving beyond "competitive interest mongering" (1984, p. 155).

\section{Inter-Component Congruence}

Democracies don't just need good institutions, they also need citizens who are willing and able to breathe life into those institutions. A version of this claim stands at the heart of classic studies of democratic consolidation (Diamond, 1999; Linz \& Stepan, 1996) as well as more recent debates about democratic deconsolidation (see Alexander \& Welzel, 2017; Foa \& Mounk, 2017; Inglehart, 2016; Norris, 2017; Voeten, 2017). The basic contention of this body of work is that democracy can be considered consolidated and stable when, among other things, democratic institutions are firmly established and citizens are meaningfully and unwaveringly supportive of democracy.

In contrast to research on democratic consolidation, research on democratic quality has made little effort to conceptualize the relationship between institutions and citizens. The widespread inclusion of (national) electoral turnout data in existing cross-national quality-ofdemocracy indices points to an underlying academic con-

\footnotetext{
${ }^{9}$ Existing quality-of-democracy indices also routinely include other participation-related indicators. The Democracy Barometer, for example, includes data on reported rates of petitioning and demonstrations; Levine and Molina (2011) include data on the share of citizens who report having worked for a candidate or party; the EIU incorporates information on membership of political parties and political non-governmental organizations as well as participation in demonstrations.

10 See, for example, Dalton (2008); Fung (2004); Mutz (2006); Norris (2002); Rosenstone and Hansen (1993); Stolle and Micheletti (2013); Verba, Nie and Kim (1978); Verba, Schlozman and Brady (1995).

11 Some scholars of political participation do not consider political discussion or political news consumption a form of political participation because-to quote Verba et al. (1995, p. 40) "the target audience is not a public official". Here we adopt a more expansive understanding of political participation that allows us to accommodate the full range of political actions identified explicitly or implied by different models of democracy.
} 
sensus that citizens are indeed conceptually constitutive of democratic quality. However, this same research has fallen short of giving any systematic conceptual consideration to how citizens matter for democratic quality beyond participation in elections. By extension, they have also failed to recognize the crucial issue that citizens matter in different ways depending on the model driving the assessment. The conceptual short shrift that researchers have given to citizens stands in marked contrast to the detailed and sophisticated discussions about how and why different kinds of institutions and structures matter for democratic quality. The goal of the previous section of this article was to address this important gap in the literature by providing a conceptual account of the citizen component of democratic quality. In this section we take a step back to address the more general conceptual question of the relationship between the citizen and institutional components of democracy.

We conceive of the relationship between institutions and citizens as it pertains to democratic quality in terms of congruence. ${ }^{12}$ As such, we follow Mayne and Geissel (2016, p. 636) in viewing the relationship between the citizen and institutional components of democratic quality as one of mutual dependence or mutual conditionality. Our basic contention therefore is that institutions and citizens represent two sides of the same democracy coin, meaning that democratic quality is a function of the level of model-specific congruence between institutions and citizen dispositions. The more institutions and citizen dispositions are simultaneously congruent with the demands and expectations of the same model of democracy, the higher that country's quality of democracy becomes, at least when judged from the viewpoint of the model in question.

Given that both the institutional and citizen components are necessary conditions of democratic quality, it is important to be clear about a key implication of our argument. If a country's political institutions accord largely with the expectations of a particular model of democracy, but citizen dispositions do not (or vice versa), we simply cannot say that this country has a high-quality democracy. How exactly inter-component incongruence would ultimately be calculated to arrive at a country's overall democracy score is a question for future empirical research. The point we wish to make is that the value of one component must, in a non-negligible way, be contingent on the value of the other component. When considering this issue of mutual contingency, it is important to distinguish between two types of inter-component congruence: one static; the other dynamic.

\subsection{Static Congruence}

When one thinks about democratic quality in terms of inter-component congruence, most likely one intuitively thinks about congruence at a single point in time, i.e., static congruence. To illustrate this form of congruence, we turn now to a brief examination of the level of fit between citizen support for direct democracy, on the one hand, and the institutionalization of direct democracy, on the other. With this worked example, to be clear, we are assessing democratic quality from the perspective of the participatory model of democracy. Given the limitations of existing cross-national data sources, we must content ourselves here with this partial illustration, which offers but a small and incomplete analytic window into understanding levels of model-specific intercomponent congruence.

Table 2 presents information, from a broad crosssection of countries, on the share of citizens who view referendums as an essential component of democracy, alongside a (national-level) measure of the actual institutionalization of direct-democratic mechanisms. ${ }^{13}$ Taken together, these indicators provide at best minimally suggestive evidence for evaluating democratic quality from the perspective of the participatory model of democracy; still they are very helpful in illustrating intercomponent congruence.

Surveying the data in Table 2, it is clear that citizen commitments and real-world institutions match in some countries but are totally "out of sync" in others. A majority of citizens in Switzerland and Uruguay support the idea that democracies should give people a direct say in political decision making; both countries also offer a range of direct-democratic mechanisms. Similarly, we observe higher levels of inter-component congruence (but in the opposite direction) in Finland, the Netherlands, and the United Kingdom, where less than 20 percent of citizens report strong participatory democratic commitments and where direct democratic mechanisms are weakly institutionalized. In contrast, we find evidence of inter-component incongruence in many other countries. Popular majorities in Cyprus, Argentina, and Germany, for example, prefer a participatory form of democracy, but direct democracy is weakly institutionalized in those countries. From the point of view of static intercomponent congruence and using this imperfect illustration of participatory democracy as the yard stick of evaluation, we would conclude that democracy is of a higher quality in Switzerland and Uruguay than in Argentina and Cyprus.

\footnotetext{
12 See Almond and Verba (1963); Eckstein (1998); Welzel and Inglehart (2006); Welzel and Klingemann (2011).

13 Data on the presence of direct democracy come from the Democracy Barometer (2012). Public opinion data come from the fifth wave of the World Value Survey (fielded between 2005 and 2009). Nationally representative samples of citizens were asked whether referendums are an essential part of democracy and provided with a 1-10 response scale, with 1 indicating that referendums are not at all essential and 10 indicating that they are definitely essential. We follow other research in using response data only for the scale maximum. As Kriesi et al. (2016, p. 67) note, survey respondents "who choose a value below the scale maximum arguably allow for exceptions and do not consider the given element as required for democracy under all circumstances".
} 
Table 2. Support for and institutionalization of direct democracy. Source: Geissel (2016).

\begin{tabular}{|c|c|c|}
\hline Country & $\begin{array}{l}\text { Support for } \\
\text { direct } \\
\text { democracy }\end{array}$ & $\begin{array}{c}\text { Institutionalization } \\
\text { of direct } \\
\text { democracy }\end{array}$ \\
\hline Argentina & 53.8 & 1 \\
\hline Australia & 46.7 & 1 \\
\hline Brazil & 43 & 1 \\
\hline Bulgaria & 39.8 & 2 \\
\hline Canada & 19.5 & 1 \\
\hline Chile & 37.9 & 0 \\
\hline Cyprus & 55.1 & 0 \\
\hline Finland & 14.3 & 0 \\
\hline France & 24.6 & 1 \\
\hline Germany & 51.8 & 0 \\
\hline Hungary & 40.9 & 3 \\
\hline Japan & 30 & 1 \\
\hline Mexico & 19.1 & 0 \\
\hline Netherlands & 17.3 & 0 \\
\hline Norway & 31.7 & 0 \\
\hline Peru & 29.8 & 3 \\
\hline Poland & 42.9 & 1 \\
\hline Romania & 43 & 1 \\
\hline Slovenia & 39.6 & 3 \\
\hline South Africa & 20.9 & 0 \\
\hline South Korea & 34.3 & 1 \\
\hline Spain & 45.8 & 0 \\
\hline Sweden & 43 & 0 \\
\hline Switzerland & 59.6 & 3 \\
\hline Turkey & 45.3 & 1 \\
\hline United Kingdom & 17 & 0 \\
\hline United States & 25.5 & 0 \\
\hline Uruguay & 50.4 & 3 \\
\hline
\end{tabular}

\subsection{Dynamic Congruence}

Over time political institutions change, as do citizen dispositions; and in many ways these changes are profoundly connected. Existing political institutions not only bound many citizens' democratic imagination, they also play an important role in shaping how citizens participate in politics as well as the political capacities they develop. Likewise, by failing to meet citizens' expectations, political institutions can generate democratic re-imaginings, stimulate and diffuse alternative forms of political participation, and encourage citizens to develop new political capacities. The opposite is also true. Elites reform political institutions in part as a response to change over time in citizens' democratic commitments, transformations in political activism, and improvements in mass political capacities. Moreover, institutional reform and changes in citizen dispositions seldom proceed in a neat, linear fashion. This means that, when viewed over a long period of time, both types of change might slowly be moving a country away from congruence with one model of democracy, toward congruence with another model.
During periods of change, however, we will necessarily observe inter-component incongruence.

From the static perspective of congruence, intercomponent incongruence lowers a country's quality of democracy, which may be misleading from a long-term perspective. It is crucial to make allowances for the processes of mutual adjustment of institutions and citizen dispositions toward new equilibria. A key analytic advantage of conceiving of inter-component congruence in both static and dynamic terms is that it allows us to distinguish between two sets of democracies. On the one hand, low-quality democracies where institutions and citizens are effectively more or less permanently out of sync with each other. And on the other hand, countries where institutions and citizen dispositions are slowly moving in the same democratic direction; and where the processes of mutual adjustment underpinning these changes are in fact a powerful positive indicator of the quality of democracy.

\section{Inter-Dispositional Consistency}

Just as different models of democracy ideally expect the institutional and citizen components of democratic quality to be congruent, they also expect-ideallydemocratic commitments, political capacities, and political participation to be consistent with each other. Interdispositional consistency (or intra-component congruence) represents an important yardstick for evaluating democratic quality, because, regardless of the model of democracy driving the assessment, a high-quality democracy depends on a particular mix and balance of commitments, capacities, and participation. For example, a high-quality participatory democracy is not just home to large numbers of citizens participating actively in politics, at and between elections, but also to large numbers of people who have the capacities to cooperate, communicate, and deliberate. Similarly, minimal-elitists might only expect citizens to participate in periodic elections, but when they do, they are also expected to be able to avoid being misled or fooled by political elites vying for their votes.

Over the years, scholars of political behavior have studied empirically how citizen dispositions relate to one another. One approach has been to examine the influence of certain kinds of democratic commitments on political participation. Recent work, by Åsa Bengtsson and Henrik Christensen (2016) and Sergiu Gherghina and Geissel (2017) finds clear associations between citizens' democratic "process preferences" and how they participate in politics. For example, citizens who support a participatory model of democracy are more likely to participate in politics (see also Bolzendahl \& Coffé, 2013; Dalton, 2008). A large body of research also exists on the question of how political capacities relate to political participation. Consistently research has found a positive association between education and political participation. Compared to the legion of studies that examines the 
impact of education, income and political interest (as a proxy of political capacity), very little research has been done on how the cognitive, expressive, and organizational capacities specifically identified by different models of democracy relate to participation. ${ }^{14}$ This is mainly due to the dearth of cross-national survey data, aimed at capturing information on political capacity. All in all, we still know very little about how the varied citizen dispositions prized by minimal-elitist, liberal-pluralist, and participatory democracy "move" together.

We now turn to some worked examples. We rely here on existing cross-national survey data, from the World Values Survey, the International Social Survey Program, the European Social Survey, and the Latin American Public Opinion Project. In particular, we focus on whether democratic commitments, using data on citizen support for referendums, align with political capacity and political participation. ${ }^{15}$ Though extremely crude, the question on referendums is helpful for the present purpose of illustrating a key aspect of citizens' demo- cratic commitments-namely, the importance of political participation beyond regular legislative elections. We use citizens' reported interest in politics as a very rough (and imperfect) overarching proxy for citizen capacity, and create an index of non-electoral political participation using available data sources. ${ }^{16}$

Figure 1 plots aggregate-level support for referendums against the share of citizens who say they are interested in politics. Examining the data from the perspective of the participatory model of democracy, it becomes clear that very few countries display a high level of inter-dispositional consistency. Only three countries (Denmark, Germany, and Switzerland) are home to citizenries with the commitments and capacities expected by participatory democrats; namely, sizeable majorities (of more than 60 percent) who see referendums as a good way to decide important political issues and who are interested in politics. In many other countries, however, participatory commitments are misaligned with political capacities. Cyprus, Croatia, Spain, and Brazil are

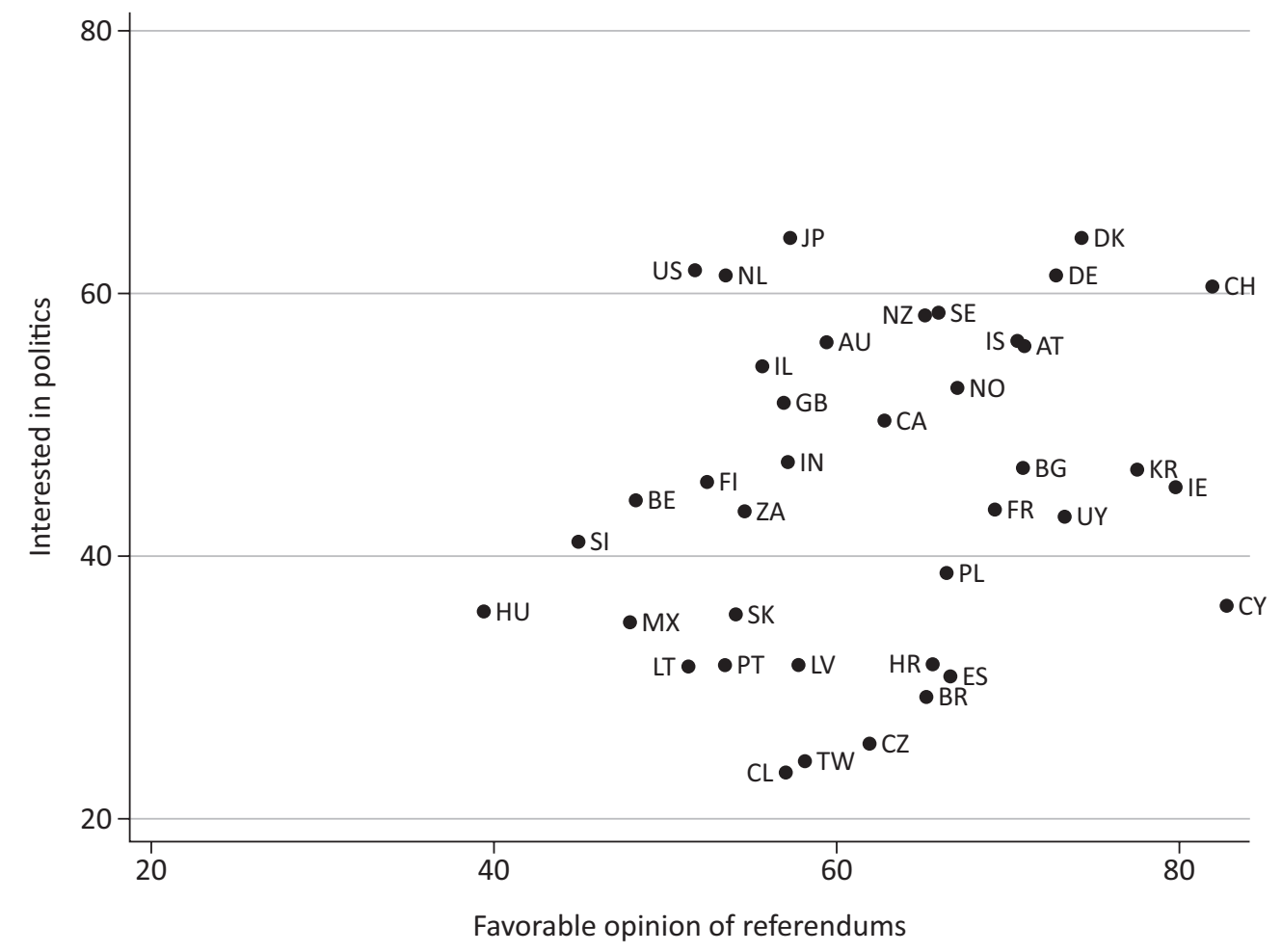

Figure 1. Interest in politics and support for direct democracy.

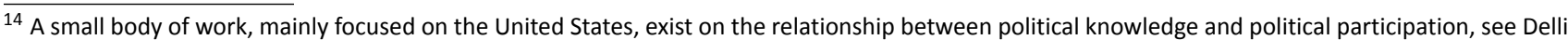
Carpini and Keeter (1996); Milner (2002); Nie et al. (1996); Verba et al. (1995).

${ }^{15}$ The question comes from two rounds of the International Social Survey Programme (ISSP, fielded in 2004 and 2014). Survey respondents were asked if they agree that referendums are a good way to decide important political questions. We report here the results for citizens who strongly agree with this statement. We aggregate (and average, where necessary) data using available population weights to produce measures of citizen dispositions that are representative of citizenries as a whole.

16 We use a question (from ISSP 2004 and 2014) about citizens' general interest in politics. Respondents who say they are very or somewhat interested in politics are combined. It is important to note, however, that the minimal-elitist model of democracy expects citizens to be interested in politics during elections, but not between them. The index of non-electoral political participation is based on three questions that appear in the ISSP (2004 and 2014), the World Values Survey, the European Social Survey, and Latin American Public Opinion Project. These relate to signing a petition, taking part in a demonstration, and contacting a public official. The index captures the share of citizens who report having undertaken at least one of these activities in the past 12 months.
} 
cases in point: large numbers of citizens favor a participatory approach to political decision making, but far fewer are interested in politics. From the perspective of minimal-elitism, only Hungary comes close to displaying ideal levels of inter-dispositional consistency. More than 60 percent of Hungarians have no strong desire for referendums and an even greater share of Hungarians say they are not interested in politics. In a number of other countries, such as Chile or the Czech Republic, we find citizenries with the kinds of political capacity (reflected in low levels of political interest) that minimal-elitists argue make for a higher-quality democracy, but who also report democratic commitments that are inconsistent with a high-quality minimal-elitist democracy. Few countries are home to citizenries with commitments and capacities consistent with a liberal-pluralist account of democracy. Belgium and Slovenia arguably come closest. In many other democracies (such as France, Uruguay, and Ireland) we find citizenries with political capacities that are consistent with liberal-pluralism, but whose democratic commitments are not.

Figure 2 once again plots our indicator of democratic commitments (namely, support for referendums), but this time against a measure of non-electoral political participation. For minimal-elitists, a high-quality democracy is one where few citizens undertake political activities between elections; the opposite is true for participatory democrats. For liberal-pluralists, democracy works best when citizens exert themselves politically between elections only when the need arises. As a result, moderate levels of non-electoral political participation are arguably most consistent with high-quality democracy from the perspective of liberal-pluralists.

Hungary is the most obvious case of minimal-elitist inter-dispositional consistency. As noted earlier, Hungarians appear to be less fond of direct democracy and very few engage in political activities between elections. Iceland, New Zealand, Canada, and Norway, among others, are home to citizenries with democratic commitments and patterns of political participation consistent with participatory democracy. Applying a liberal-pluralist benchmark, Belgium and the Netherlands appear to come closest to displaying the desired types and levels of political participation and democratic commitments. Most countries, however, are home to large numbers of people with mixed patterns of citizen dispositions that are inconsistent with any one model of democracy.

\section{Conclusion}

In this article we have argued that democratic quality depends not only on the form and functioning of democratic institutions but also on the dispositions of citizens. ${ }^{17}$ To date, however, cross-national indices have focused predominantly on the institutional component of democratic quality, the measures of which have become

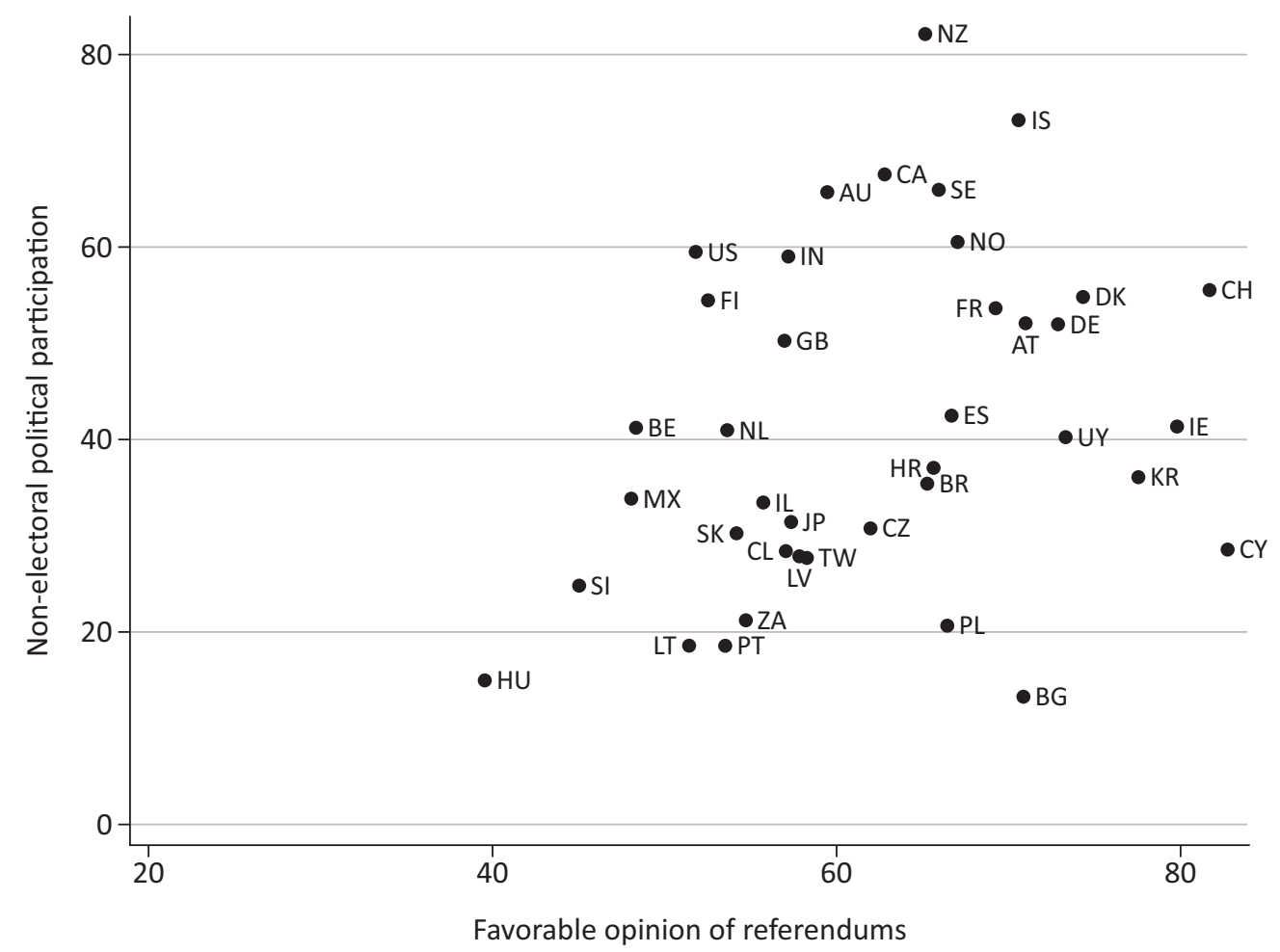

Figure 2. Non-electoral political participation and support for direct democracy.

\footnotetext{
17 Democratic quality also depends on the dispositions of political elites, most obviously their commitment to democracy as well as their level of political competence (see, for example, Linz \& Stepan, 1996; Mainwaring \& Pérez-Liñán, 2013; Steiner, Bächtiger, Spörndli, \& Steenbergen, 2004).
} 
increasingly multidimensional and conceptually sophisticated. The Varieties of Democracy program (Coppedge et al., 2011) has enriched this approach by making it possible to systematically evaluate democratic institutions according to different models of democracy. The same cannot be said of the citizen component of democratic quality. Existing indices commonly incorporate information on national turnout rates, which points to an academic consensus that citizens are indeed a constitutive element of democratic quality. Few other citizen-related indicators are, however, included, and when they are it is often with little theoretical justification. The result is that citizens play conceptual second fiddle to institutions, and there is little or no recognition that different accounts of democracy demand and expect different kinds of citizen dispositions. Our aim with this article is to challenge this orthodoxy by providing a structured account of the citizen component of democratic quality, with a focus on three models of democracy-minimal-elitism, liberalpluralism, and participatory democracy.

The first section of the article provided a fine-grained conceptualization of what we argue are the three core dispositions that make up the citizen component of democratic quality-namely, democratic commitment, political capacity, and political participation. We made the case that commitment is not just about general support for democracy but also model-specific commitments related to who gets to decide and how decisions are to be made in the political arena. We defined political capacity in terms of citizens' ability to know, choose, and influence, identifying key differences in how the three models conceive of political capacity. Finally, to capture the kinds and levels of political participation that different models of democracy expect of citizens, we argued that scholars of democratic quality should focus on the weight attached to: election-focused participation versus participation between elections; mediated versus direct forms of political action; and "other-regarding" political participation that brings together citizens with divergent political viewpoints.

The second and third sections of the article deal with two key issues that arise when taking citizens seriously in the conceptualization of democratic quality. The first is the issue of "fit" between institutions and citizens, which we refer to as inter-component congruence. Specifically, we made the case that any assessment of democratic quality must consider the extent to which both institutions and citizen dispositions are congruent with the same model of democracy. We further underscored the importance of distinguishing static congruence-where democratic quality is judged according to the level of inter-component congruence at single point in time, and dynamic congruence-where democratic quality is judged according to long-term processes of mutual adjustment between institutions and citizen disposition toward the same model of democracy.
The other significant issue we addressed was interdispositional consistency. Ideally, we argued, democratic commitments, capacities, and participation should all be consistent with the same model of democracy. To illustrate this point we turned to an analysis of existing cross-national survey data, which provided suggestive evidence that citizen dispositions are highly inconsistent with each other in many democracies. Cognizant of the imperfections of the available data, this nonetheless has important implications when developing composite measures of the citizen component of democratic quality.

The greatest challenge moving forward with our conceptualization of democratic quality relates to data availability. In writing this article we undertook a systematic and broad survey of existing cross-national surveys. ${ }^{18}$ Our aim was to identify questions that could serve as indicators to operationalize the citizen component of democratic quality. In some regards, existing cross-national survey programs provide a solid foundation to build on; in other respects, however, much work remains to be done. In recent years, the measurement of democratic commitments has improved greatly. Wellestablished questions that gauge citizens' general support for democracy have been supplemented with new batteries of questions shedding light on citizens' commitment to specific democratic principles, capturing information on a variety of democratic principles shared by all key models of democracy. There has, however, been some effort to include one or two questions that allow researchers to distinguish commitments to principles specific to minimal-elitist, liberal-pluralist, and participatory accounts of democracy. One goal of this article has been to provide a fuller account of the commitments expected of citizens by different models of democracy.

We also found that the measurement of political participation is fairly strong, with information being frequently collected on a broad range of non-electoral forms of participation. It is difficult though to isolate "other-regarding" forms of political participation, which are important for liberal-pluralist and participatory accounts of democracy. Given the challenges of political polarization and social division that face many democratic societies today, future quality-of-democracy research would therefore benefit from being able to measure how much citizens are actually engaging in political activities that involve encountering and working with others with different political viewpoints.

Finally, and most worrying of all, we found that the measurement of political capacities is weak. Crossnational surveys often ask citizens to self-report on their general sense of political understanding or competence. Some surveys also gauge citizens' level of political knowledge, but developing cross-nationally commensurable measures of political knowledge has been challenging (Gidengil, Meneguello, Shenga, \& Zechmeister, 2016). Overall though, unlike some surveys carried out in in-

\footnotetext{
18 This included the World Values Survey, ISSP, European Social Survey, Comparative Study of Electoral Systems, European Election Study, and Latin American Public Opinion Project.
} 
dividual countries, to date no cross-national measures have been fielded aimed at directly capturing information on citizens' cognitive, expressive, and organizational capacities. This is not to underestimate the difficulty of developing valid and reliable empirical indicators of political capacity, but the lack of data in this area poses a real problem for quality-of-democracy research. As we have argued in this article, citizens' capacity to know, choose, and influence in the political arena is central to the quality of democracy. By detailing how different models of democracy understand these three capacities in different ways, we hope that this article provides a valuable resource for developing new survey questions to fully incorporate the citizen component into future quality-ofdemocracy research.

\section{Acknowledgments}

We thank the anonymous reviewers and Heiko Giebler, Saskia Ruth, and Dag Tanneberg, editors of this thematic issue, for their valuable feedback. We also thank participants of a special issue workshop, held at the University of Zurich in June 2017, and members of the democratic innovations research group at Goethe University Frankfurt for their helpful comments. Finally, we thank Anna Krämling for research assistance.

\section{Conflict of Interests}

The authors declare no conflict of interests.

\section{References}

Achen, C. H., \& Bartels, L. M. (2016). Democracy for realists: Why elections do not produce responsive government. Princeton, NJ: Princeton University Press.

Alexander, A. C., \& Welzel, C. (2017). The myth of deconsolidation: Rising liberalism and the populist reaction. Journal of Democracy (Web Exchange). Retrieved from https://www.journalofdemocracy.org/onlineexchange-\%E2\%80\%9Cdemocratic-deconsolidation\% E2\%80\%9D

Almond, G. A., \& Verba, S. (1963). The civic culture: Political attitudes and democracy in five nations. Princeton, NJ: Princeton University Press.

Altman, D., \& Pérez-Liñán, A. (2002). Assessing the quality of democracy: Freedom, competitiveness and participation in eighteen Latin American Countries. Democratization, 9(2), 85-100.

Alvarez, M. E., \& Nagler, J. (2000). A new approach for modelling strategic voting in multiparty elections. British Journal of Political Science, 30(1), 57-75.

Andersen, R., Tilley, J., \& Heath, A. F. (2005). Political knowledge and enlightened preferences: Party choice through the electoral cycle. British Journal of Political Science, 35(2), 285-302.

Arnold, J. R. (2012). The electoral consequences of voter ignorance. Electoral Studies, 31(4), 796-815.
Barabas, J., \& Jerit, J. (2009). Estimating the causal effects of media coverage on policy-specific knowledge. American Journal of Political Science, 53(1), 73-89.

Barber, B. R. (1984). Strong democracy: Participatory politics for a new age. Berkeley, CA: University of California Press.

Bartels, L. M. (1996). Uninformed votes: Information effects in presidential elections. American Journal of Political Science, 40(1), 194-230.

Bengtsson, Å., \& Christensen, H. (2016). Ideals and actions: Do citizens' patterns of political participation correspond to their conceptions of democracy? Government and Opposition, 51(2), 234-260.

Bolzendahl, C., \& Coffé, H. (2013). Are 'good' citizens 'good' participants? Testing citizenship norms and political participation across 25 nations. Political Studies, 61(S1), 45-65.

Bratton, M., Mattes, R. B., \& Gyimah-Boadi, E. (2005). Public opinion, democracy, and market reform in Africa. Cambridge and New York, NY: Cambridge University Press.

Bühlmann, M., Merkel, W., Müller, L., Giebler, H., Wessels, B., Boschler, D., . . Bousbah, K. (2013). Democracy barometer. Codebook for blueprint dataset version 3. Aarau: Zentrum für Demokratie.

Campbell, A., Converse, P. E., Miller, W. E., \& Stokes, D. E. (1960). The American voter. Chicago, IL: University of Chicago Press.

Campbell, D. (2008). The basic concept for the democracy ranking of the quality of democracy. Vienna: Democracy Ranking.

Canache, D. (2012). Citizens' conceptualizations of democracy: Structural complexity, substantive content, and political significance. Comparative Political Studies, 45(9), 1132-1158.

Carlin, R. E. (2017). Sorting out support for democracy: A q-method study. Political Psychology, 1-24. doi:10.1111/pops.12409

Carlin, R. E., \& Singer, M. M. (2011). Support for polyarchy in the Americas. Comparative Political Studies, 44(11), 1500-1526.

Carrión, J. F. (2008). Illiberal democracy and normative democracy: How is democracy defined in the Americas? In M. A. Seligson (Ed.), Challenges to democracy in Latin America and the Caribbean: Evidence from the Americas Barometer 2006-2007 (pp. 21-51). Nashville, TN: Latin American Public Opinion Project, Vanderbilt University.

Converse, P. E. (1964). The nature of belief systems in mass publics. In D. E. Apter (Ed.), Ideology and discontent (pp. 75-169). New York, NY: Free Press.

Coppedge, M., Gerring, J., Altman, D., Bernhard, M., Fish, S., Hicken, A., . . . Teorell, J. (2011). Conceptualizing and measuring democracy: A new approach. Perspectives on Politics, 9(2), 247-267.

Dahl, R. A. (1971). Polyarchy: Participation and opposition. New Haven, CT: Yale University Press. 
Dahl, R. A. (1989). Democracy and its critics. New Haven, CT: Yale University Press.

Dalton, R. J. (2008). Citizenship norms and the expansion of political participation. Political Studies, 56(1), 76-98.

Dalton, R. J., Sin, T., \& Jou, W. (2007). Understanding democracy: Data from unlikely places. Journal of Democracy, 18(4), 142-156.

Delli Carpini, M. X., \& Keeter, S. (1996). What Americans know about politics and why it matters. New Haven, CT: Yale University Press.

Diamond, L. J. (1999). Developing democracy: Toward consolidation. Baltimore, MD, and London: Johns Hopkins University Press.

Eckstein, H. (1998). Congruence theory explained. In H. Eckstein (Ed.), Can democracy take root in Post-Soviet Russia? Explorations in state-society relations (pp. 3-34). Lanham, MD: Rowman and Littlefield.

Economist Intelligence Unit. (2012). Democracy index. London: Economist Intelligence Unit.

Foa, R. S., \& Mounk, Y. (2017). The signs of deconsolidation. Journal of Democracy, 28(1), 5-15.

Fuchs, D., \& Roller, E. (2006). Learned democracy? Support of democracy in central and eastern Europe. International Journal of Sociology, 36(3), 70-96.

Fung, A. (2004). Empowered participation: Reinventing urban democracy. Princeton, NJ: Princeton University Press.

Galston, W. A. (1988). Liberal virtues. The American Political Science Review, 82(4), 1277-1290.

Geissel, B. (2016). Should participatory opportunities be a component of democratic quality? The role of citizen views in resolving a conceptual controversy. International Political Science Review, 37(5), 656-665.

Gherghina, S., \& Geissel, B. (2017). Linking democratic preferences and political participation: Evidence from Germany. Political Studies, 65(S1), 24-42.

Gidengil, E., Meneguello, R., Shenga, C., \& Zechmeister, E. (2016). Political knowledge sub-committee report. Final Report of CSES Module 5 Political Knowledge Subcommittee. Retrieved from http://www.cses.org/ plancom/module5/CSES5_PoliticalKnowledgeSub committee_FinalReport.pdf

Hibbing, J. R., \& Theiss-Morse, E. (2002). Stealth democracy: Americans' beliefs about how government should work. New York, NY: Cambridge University Press.

Inglehart, R. (2016). How much should we worry? Journal of Democracy, 27(3), 18-23.

Kornberg, A., \& Clarke, H. D. (1994). Beliefs about democracy and satisfaction with democratic government: The Canadian case. Political Research Quarterly, 47(3), 537-563.

Kriesi, H., Saris, W., \& Moncagatta, P. (2016). The structure of Europeans' views of democracy. In M. Ferrín \& H. Kriesi (Eds.), How Europeans view and evaluate democracy (pp. 64-89). Oxford and New York, NY: Oxford University Press.
Kymlicka, W., \& Norman, W. (1994). Return of the citizen: A survey of recent work on citizenship theory. Ethics, 104(2), 352-381.

Lalljee, M., Evans, G., Sarawgi, S., \& Voltmer, K. (2013). Respect your enemies: Orientations towards political opponents and political involvement in Britain. International Journal of Public Opinion Research, 25(1), 119-131.

Lau, R. R., Patel, P., Fahmy, D. F., \& Kaufman, R. R. (2014). Correct voting across thirty-three democracies: A preliminary analysis. British Journal of Political Science, 44(2), 239-259.

Lavine, H., Johnston, C. D., \& Steenbergen, M. R. (2012). The ambivalent partisan: How critical loyalty promotes democracy. New York, NY: Oxford University Press.

Levine, D. H., \& Molina, J. E. (Eds.). (2011). The quality of democracy in Latin America. Boulder, CO: Lynne Rienner.

Levitsky, S., \& Ziblatt, D. (2018). How democracies die. New York, NY: Crown Publishing.

Lijphart, A. (1999). Patterns of democracy: Government forms and performance in thirty-six countries. New Haven, CT: Yale University Press.

Linz, J. J., \& Stepan, A. (1996). Problems of democratic transition and consolidation: Southern Europe, South America, and post-communist Europe. Baltimore, MD, and London: The Johns Hopkins University Press.

Lodge, M., \& Taber, C. S. (2013). The rationalizing voter. New York, NY: Cambridge University Press.

Logan, C., \& Mattes, R. (2012). Democratising the measurement of democratic quality: Public attitude data and the evaluation of African political regimes. European Political Science, 11(4), 469-491.

Lupia, A. (2016). Uninformed: Why people know so little about politics and what we can do about it. New York, NY: Oxford University Press.

Macedo, S. (1990). Liberal virtues: Citizenship, virtue, and community in liberal constitutionalism. Oxford: Clarendon Press.

Mainwaring, S., Brinks, D., \& Pérez-Liñán, A. (2007). Classifying political regimes in Latin America, 1945-2004. In G. L. Munck (Ed.), Regimes and democracy in Latin America: Theories and methods (pp. 123-160). New York, NY: Oxford University Press.

Mainwaring, S., \& Pérez-Liñán, A. (2013). Democracies and dictatorships in Latin America: Emergence, survival, and fall. New York, NY: Cambridge University Press.

Mayne, Q., \& Geissel B. (2016). Putting the demos back into the concept of democratic quality. International Political Science Review, 37(5), 634-44.

McClosky, H. (1964). Consensus and ideology in American politics. American Political Science Review, 58(2), 361-382.

Mill, J. S. (2009). Representative government. Munich: GRIN. (Original work published 1861) 
Miller, A. H., Hesli, V. L., \& Reisinger, W. M. (1997). Conceptions of democracy among mass and elite in postSoviet societies. British Journal of Political Science, 27(2), 157-190.

Milner, H. (2002). Civic literacy: How informed citizens make democracy work. Hanover, NH: Tufts University-University Press of New England.

Mutz, D. C. (2006). Hearing the other side: Deliberative versus participatory democracy. New York, NY: Cambridge University Press.

Nie, N. H., Junn, J., \& Stehlik-Barry, K. (1996). Education and democratic citizenship in America. Chicago, IL: University of Chicago Press.

Norris, P. (2002). Democratic phoenix: Reinventing political activism. Cambridge and New York, NY: Cambridge University Press.

Norris, P. (2017). Is Western democracy backsliding? Diagnosing the risks. Journal of Democracy (Web Exchange). Retrieved from https://www.journalof democracy.org/online-exchange-\%E2\%80\%9Cdemo cratic-deconsolidation\%E2\%80\%9D

Page, B. I., \& Shapiro, R. Y. (1992). The rational public: Fifty years of trends in Americans' policy preferences. Chicago, IL: University of Chicago Press.

Pateman, C. (1970). Participation and democratic theory. Cambridge: Cambridge University Press.

Pickel, S., Breustedt, W., \& Smolka, T. (2016). Measuring the quality of democracy: Why include the citizens' perspective? International Political Science Review, 37(5), 645-655.

Przeworski, A., Alvarez, M. E., Cheibub, J. A., \& Limongi, F. (2000). Democracy and development: Political institutions and well-being in the world, 1950-1990. New York, NY: Cambridge University Press.

Rapeli, L. (2014). The conception of citizen knowledge in democratic theory. Basingstoke and New York, NY: Palgrave Macmillan.

Rosema, M., \& de Vries, C. E. (2011). Assessing the quality of European democracy: Are voters voting correctly. In S. A. H. Denters, M. Rosema, \& K. Aarts (Eds.), How democracy works: Political representation and policy congruence in modern societies: Essays in honour of Jacques Thomassen (pp. 199-217). Amsterdam: Pallas Publications.

Rosenstone, S. J., \& Hansen, J. M. (1993). Mobilization, participation, and democracy in America. New York, NY: Pearson Education.

Schattschneider, E. E. (1975). The semisovereign people:
A realist's view of democracy in America. Boston, MA: Wadsworth.

Schedler, A., \& Sarsfield, R. (2007). Democrats with adjectives: Linking direct and indirect measures of democratic support. European Journal of Political Research, 46(5), 637-659.

Schumpeter, J. A. (1950). Capitalism, socialism, and democracy (3rd ed.). New York, NY, and London: Harper \& Brothers.

Silveira, L., \& Heinrich, H.-A. (2017). Drawing democracy: Popular conceptions of democracy in Germany. Quality \& Quantity, 51(4), 1645-1661.

Steiner, J., Bächtiger, A., Spörndli, M., \& Steenbergen, M. R. (2004). Deliberative politics in action: Analyzing parliamentary discourse. New York, NY: Cambridge University Press.

Stolle, D., \& Micheletti, M. (2013). Political consumerism: Global responsibility in action. New York, NY: Cambridge University Press.

Thomassen, J. (1995). Support for democratic values. In H.-D. Klingemann \& D. Fuchs (Eds.), Citizens and the state (Vol. 1, pp. 383-416). New York, NY: Oxford University Press.

Verba, S., Nie, N. H., \& Kim, J.-O. (1978). Participation and political equality: A seven-nation comparison. Cambridge and New York, NY: Cambridge University Press.

Verba, S., Schlozman, K. L., \& Brady, H. E. (1995). Voice and equality: Civic voluntarism in American politics. Cambridge, MA: Harvard University Press.

Voeten, E. (2017). Are people really turning away from democracy? Journal of Democracy (Web Exchange). Retrieved from https://www.journalofdemocracy. org/online-exchange-\%E2\%80\%9Cdemocratic-decon solidation\%E2\%80\%9D

Welzel, C., \& Inglehart, R. (2006). Emancipative values and democracy: Response to Hadenius and Teorell. Studies in Comparative International Development, 41(3), 74-94.

Welzel, C., \& Klingemann, H.-D. (2011). Democratic congruence re-established: The perspective of "substantive" democracy. In M. Rosema, B. Denters, \& K. Aarts (Eds.), How democracy works: Political representation and policy congruence in modern societies ( $\mathrm{pp}$. 89-114). Amsterdam: Pallas Publications.

Zaller, J. R. (1992). The nature and origins of mass opinion. New York, NY: Cambridge University Press.

\section{About the Authors}

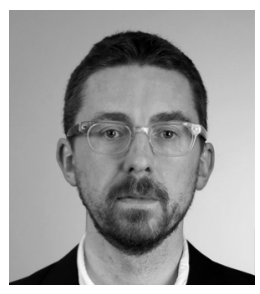

Quinton Mayne (PhD, Princeton) is Associate Professor of Public Policy at the Kennedy School of Government at Harvard University. His main research interests lie at the intersection of comparative and urban politics, with a particular interest in political behavior and social policy in advanced industrial democracies. 


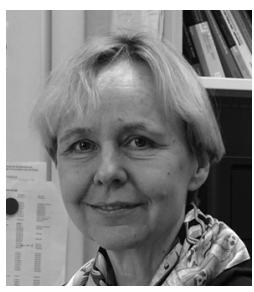

Brigitte Geissel (PhD, TU Berlin) is professor of political science and sociology at Goethe University Frankfurt. Her research interests include democratic innovations, new forms of governance, and political actors (new social movements, associations, civil society, parties, political elites, citizens). 